\title{
Matúš MARGETIN*, Vladimír CHMELKO** \\ EXPERIMENTAL QUANTIFICATION OF THE FATIGUE STRESS CONCENTRATOR ON MIG BUTT WELDED S355 STEEL SPECIMEN
}

\section{EXPERIMENTÁLNE STANOVENIE ÚNAVOVÉHO VRUBOVÉHO SÚČINITELAA NAPÄTIA PRE VZORKY Z OCELE S355 ZVÁRANÉ TECHNOLÓGIOU MIG}

\begin{abstract}
Joining components by welding is the most widespread method of joining for metal structures. For this reason, fatigue strength assessment of welded joints is of great interest to engineers involved in structure design. The welded joint itself can be considered a notch composed of a technological (inner deffects and material inhomogenities) and a geometrical (surface irregularities) part. Due to stress and strain concentration, such a notch decreases fatigue endurance of a welded construction. This paper shows experimental quantification of the fatigue stress notch factor for butt welded joints manufactured by MIG technology.
\end{abstract}

\section{Abstrakt}

Technológia zvárania je pri kovových konštrukciách najrozšírenejšou metódou spájania konštrukčných častí. Z tohto dôvodu je problematike posudzovania únavovej životnosti zvarových spojov venovaná zvýšená pozornost' strojných inžinierov. Na zvar ako taký možno pozerat' ako na vrub pozostávajúci z technologickej (vnútorné chyby a nehomogenity materiálu) a geometrickej (povrchová členitost') časti. Tento vrub vplyvom koncentrácie napätia a deformácie znižuje únavovú odolnost' konštrukcie. Obsahom tohoto príspevku je kvantifikácia únavového vrubového súčinitel'a napätia pre tupý zvar vyhotovený technológiou MIG.

\section{Keywords}

fatigue, welded joint, notch, stress concentrator, life time analysis

\section{INTRODUCTION}

In the design of construction joints, the most helpful thing to constructors is usually a list of recommendations in the form of norms. In Slovakia (and also in Europe), the official document that deals with the design of welded constructions is the EUROCODE 3 [1]. The critical analysis that has been executed on a wide spectrum of real cases has shown that official directives are often inaccurate and overestimate loading conditions in fatigue life time analysis, which results in the design of robust and expensive constructions [2].

In order to achieve a more accurate estimation of the fatigue lifetime of welded joints, we can define and approach the welded joints as a combination of a technological (material inhomogeneity

\footnotetext{
Ing. PhD., Institute of Aplied Mechanics and Mechatronics, Faculty of Mechanical Enginering, Slovak University of Technology, Námestie slobody 17, Bratislava, tel. (+421) 257296111, e-mail: matus.margetin@stuba.sk

*** Ing. PhD., Institute of Aplied Mechanics and Mechatronics, Faculty of Mechanical Enginering, Slovak University of Technology, Námestie slobody 17, Bratislava, tel. (+421) 257296111, e-mail: vladimir.chmelko@stuba.sk
} 
such as different hardness around weld bead which leads to different fatigue behavior of material around the weld [3]) and a geometrical (geometrical irregularities of the weld bead) notch. To quantify the (technological and geometrical) notch effect of the welded joint, an experiment on three types of specimens has been carried out. The design of the experiment is described in more detail in the article [4]. In the next chapters, a short overview, results and conclusions from this experiment will be presented.

\section{EXPERIMENT}

Fatigue tests with a constant stress amplitude have been carried out on three types of specimens - on an unwelded specimen and on specimens with (technological notch) and without (technological and geometrical notch) a manufactured weld bead Fig.1.

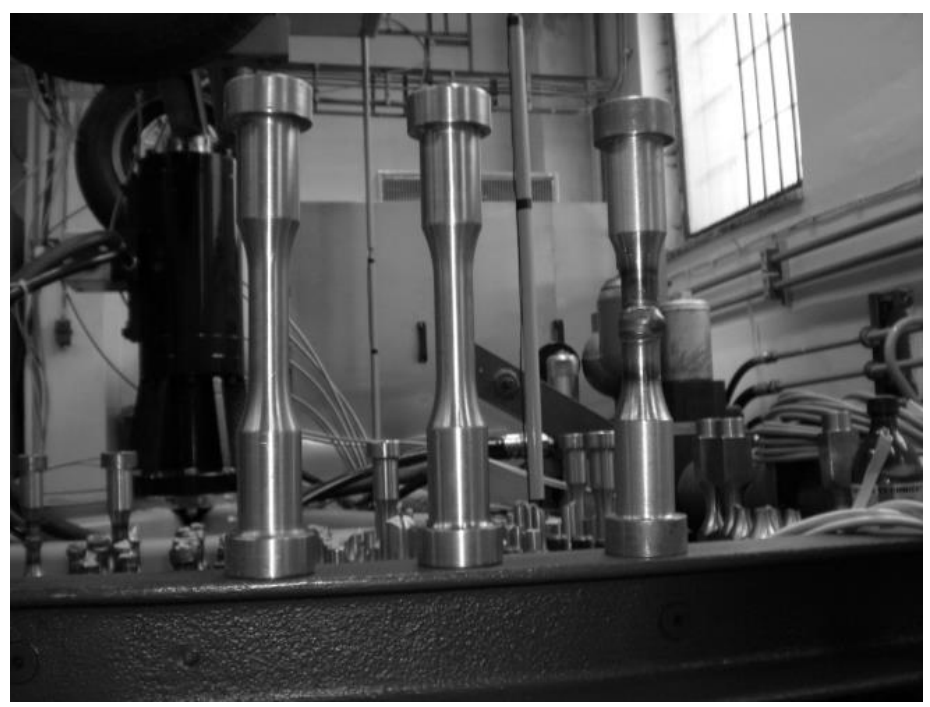

Fig. 1 From left to right: unwelded specimens, manufactured welded specimens, specimens without a manufactured weld bead.

The foundational semiproduct of all three types of testing specimens is the steel pole $\varnothing 35 \mathrm{~h} 7$ from material $11523(\mathrm{~S} 355 \mathrm{~J} 2 \mathrm{C}+\mathrm{C})$. The weld itself was manufactured by the MIG technology and during the process, in order to achieve a complete join of the testing specimen it was necessary to execute three layers of the weld bead. The material characteristics of the base material and of the welded metal are in the Table 1.

Tab. 1 Material properties

\begin{tabular}{|c|c|c|c|c|c|c|c|c|c|c|}
\hline $\begin{array}{c}\mathrm{Rp} 0,2 \\
{[\mathrm{MPa}]}\end{array}$ & $\begin{array}{c}\mathrm{Rm} \\
{[\mathrm{MPa}]}\end{array}$ & $\begin{array}{c}\mathrm{A} 5 \\
{[\%]}\end{array}$ & $\begin{array}{c}\mathrm{C} \\
{[\%]}\end{array}$ & $\begin{array}{c}\mathrm{P} \\
{[\%]}\end{array}$ & $\mathrm{S}[\%]$ & $\begin{array}{c}\mathrm{Mn} \\
{[\%]}\end{array}$ & $\begin{array}{c}\mathrm{Si} \\
{[\%]}\end{array}$ & $\begin{array}{c}\mathrm{Cu} \\
{[\%]}\end{array}$ & $\begin{array}{c}\mathrm{Al} \\
{[\%]}\end{array}$ & $\begin{array}{c}\mathrm{CEV} \\
{[\%]}\end{array}$ \\
\hline \multicolumn{10}{|c|}{ Steel $11523(\mathrm{~S} 355 \mathrm{~J} 2 \mathrm{C}+\mathrm{C})$} \\
\hline 612 & 644 & 19 & 0.19 & 0.018 & 0.017 & 1.32 & 0.4 & 0.06 & 0.035 & 0.44 \\
\hline \multicolumn{10}{|c|}{ Weld cord CARBOFIL 1A GOLD, OERLIKON } \\
\hline 460 & $550-630$ & 24 & 0.06 & 0.02 & 0.03 & 1.7 & 0.9 & - & - & - \\
\hline
\end{tabular}




\subsection{Fatigue curves of welded joint}

The fatigue tests of the welded joint were executed on a servo-hydraulic test machine EDYZ-6 from INOVA company placed in laboratories of the Institute of Applied Mechanics and Mechatronics at the Faculty of Mechanical Engineering, Slovak University of Technology. Results from these experiments have been statistically processed in the form of Basquin equation:

$$
\sigma_{a}=\sigma_{f}^{\prime}\left(2 N_{f}\right)^{b}
$$

where:

$\sigma_{f}^{\prime} \quad$ - fatigue strength coefficient $[M P a]$,

$b \quad$ - fatigue strength exponent [-],

$N_{f} \quad$ number of loading cycles [-],

$\sigma_{a} \quad$ stress amplitude $[\mathrm{MPa}]$.

The experimental results for all three types of specimen in the statistical form can be found in Tab. 2. Fig. 2 shows Basquin curves for three types of specimens in logarithmic coordinates in the range of a high-cycle fatigue. Basquin relation does not provide any real results in the range of a lowcycle fatigue. This phenomenon is caused by a great plastic deformation. In the range of the lowcycle fatigue, strain base method should be used [5].

Tab. 2 Parameters of Basquin curves for three types of specimens

\begin{tabular}{|c|c|c|c|c|c|c|}
\hline & \multirow[t]{2}{*}{ Mean } & \multicolumn{2}{|c|}{$\begin{array}{c}\text { Confidence Interval } \\
{[\mathrm{P}=95 \%]}\end{array}$} & \multicolumn{2}{|c|}{ Prediction Interval $[\mathrm{P}=95 \%]$} & \multirow[t]{2}{*}{$\begin{array}{l}\text { Correlation } \\
\text { coefficient }\end{array}$} \\
\hline & & Upper limit & Lower limit & Upper limit & Lower limit & \\
\hline \multicolumn{7}{|c|}{ Unwelded specimens } \\
\hline$\sigma_{\mathrm{f}}^{\prime}[\mathrm{MPa}]$ & 579.4324 & 582.2639 & 576.6146 & 595.0888 & 564.1807 & -0.9781 \\
\hline $\mathrm{b}[-]$ & -0.0504 & -0.0504 & -0.0504 & -0.05039 & -0.05041 & \\
\hline \multicolumn{7}{|c|}{ Manufactured welded specimens } \\
\hline$\sigma_{\mathrm{f}}^{\prime}[\mathrm{MPa}]$ & 678.6126 & 691.9738 & 665.5093 & 765.8374 & 601.7352 & -0.95496 \\
\hline $\mathrm{b}[-]$ & -0.12042 & -0.12041 & -0.12042 & -0.12076 & -0.12007 & \\
\hline \multicolumn{7}{|c|}{ Specimens without manufactured weld bead } \\
\hline$\sigma_{\mathrm{f}}^{\prime}[\mathrm{MPa}]$ & 13661.53 & 14175.88 & 13165.85 & 16347.77 & 11379.48 & -0.93854 \\
\hline $\mathrm{b}[-]$ & -0.37184 & -0.37185 & -0.37184 & -0.36852 & -0.37522 & \\
\hline
\end{tabular}




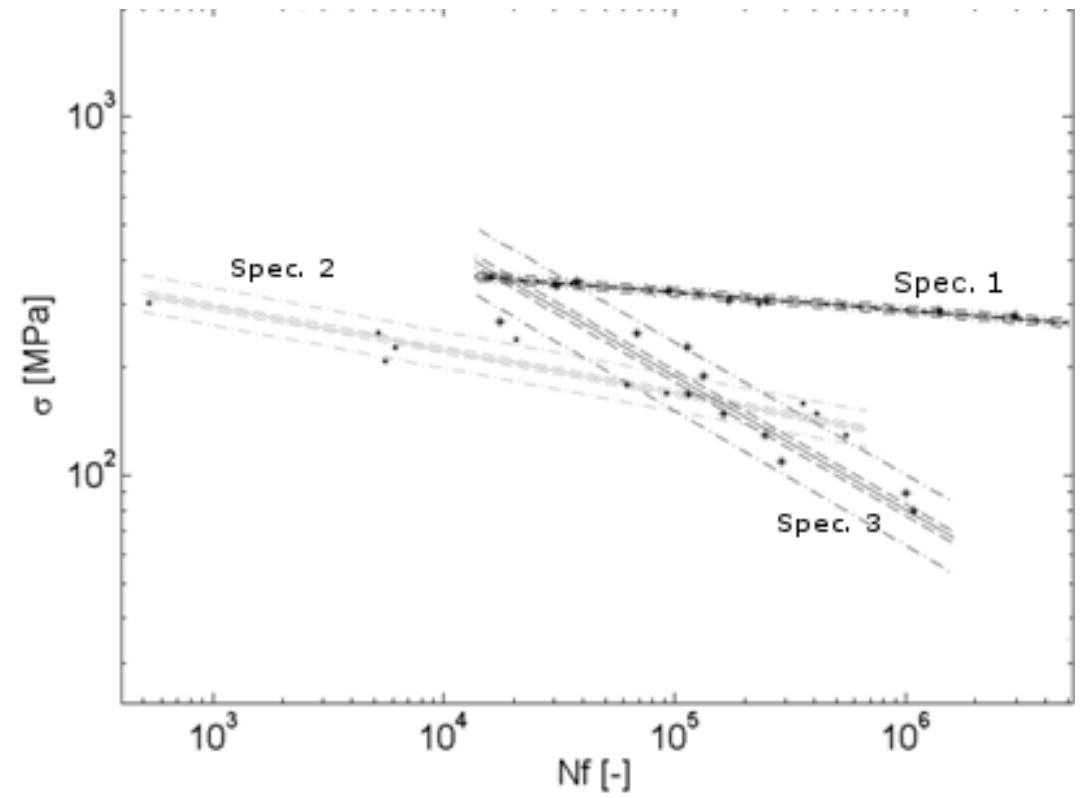

Fig. 2 Comparison of Basquin curves of all three sets of specimens: 1 - unwelded specimens, 2 manufactured welded specimens, 3 - specimens without a manufactured weld bead.

\subsection{The Fatigue stress notch factor.}

The fatigue stress notch factor as a function of loading cycles [6] can be obtained by comparing the fatigue curves of the welded and the unwelded specimens:

$$
\beta_{\sigma\left(2 N_{f}\right)}=\frac{\sigma_{U\left(2 N_{f}\right)}}{\sigma_{U k\left(2 N_{f}\right)}}
$$

where:

$\sigma_{U}$ - stress amplitude according to given number of cycles to failure for notched component $[M P a]$,

$\sigma_{U k}$ - stress amplitude according to given number of cycles to failure for smooth component $[M P a]$,

$\beta \sigma \quad$ - fatigue stress notch factor according to given number of cycles to failure [-],

$N_{f} \quad$ number of cycles [-].

The fatigue stress notch factor as a function of number of cycles to failure for both welded specimen types can be seen in Fig.3. 


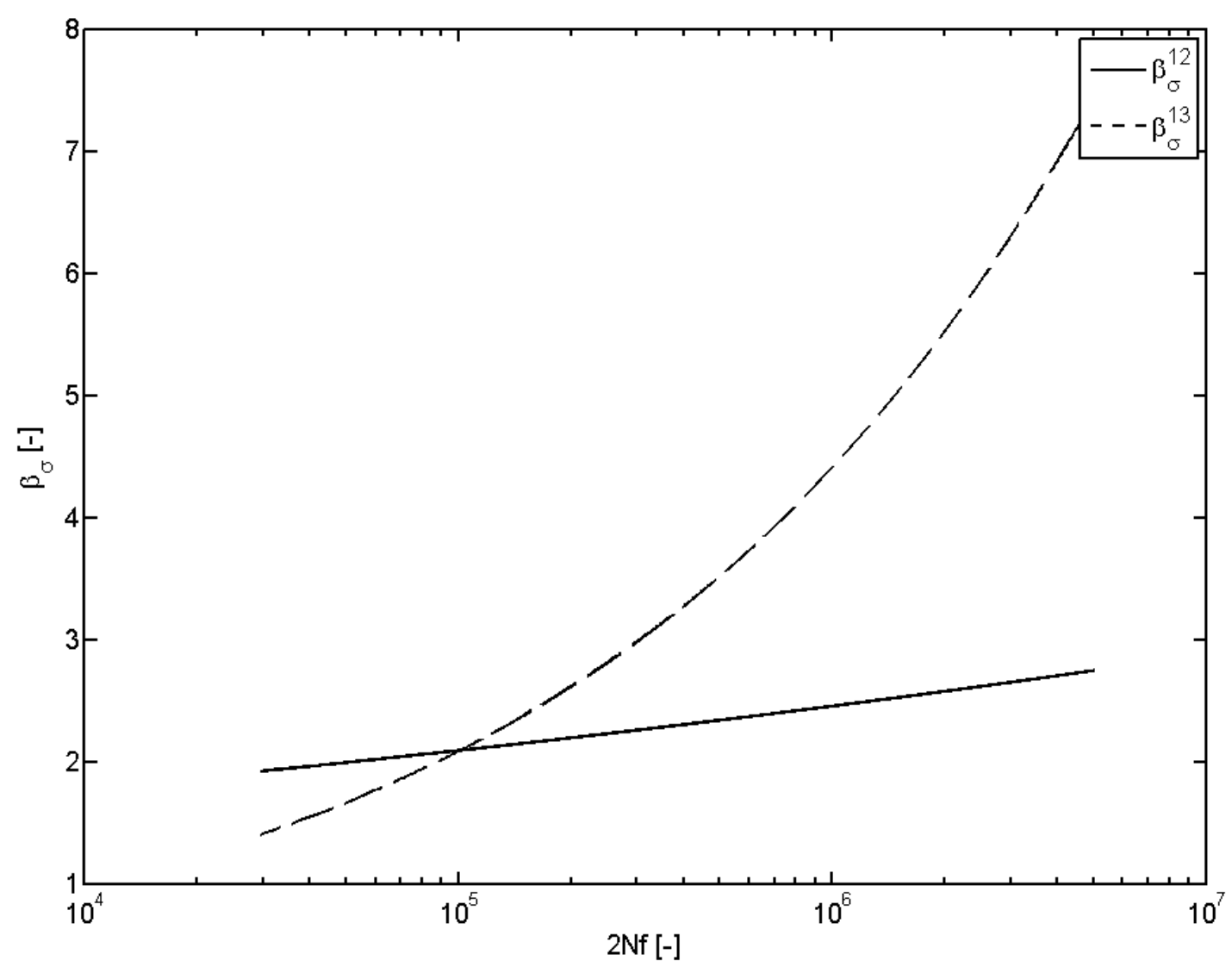

Fig. 3 Fatigue stress notch factor as a function of number of cycles to failure: $\beta_{\sigma}{ }^{12}$ - manufactured welded specimens, $\beta_{\sigma}{ }^{13}$ - specimens without a manufactured weld bead.

\section{CONCLUSIONS}

Based on experimentally obtained curves, following conclusion can be postulated:

- Regarding fatigue lifetime estimation, a welded joint can be considered a stress concentrator which decreases a fatigue lifetime of a construction.

- The technological and the geometrical notch decrease fatigue lifetime of a welded joint. Whereas the geometrical notch is dominant in the areas of lower stresses (with lifetimes of $\left.1-2 * 10^{5}\right)$, in the areas of higher stresses, the technological notch becomes dominant.

- The effect the technological notch has on the fatigue lifetime of the unmanufactured welded joint is largely eliminated by enlargement of the cross-section in the place of the presumed occurence of the largest number of subsurface defects. This fact can actually be the reason why the real stress peak around internal defects is during a smaller nominal loading lower than the stress in the weld toe, despite the fact that the internal defects themselves can represent a larger stress concentrator than the weld toe.

- In manufactured welded joints, the place of a fatigue crack initiation is most often the inner defect Fig 4. On the other hand, in joints with as-weld conditions, the fatigue crack initiates mainly in the weld toe. 


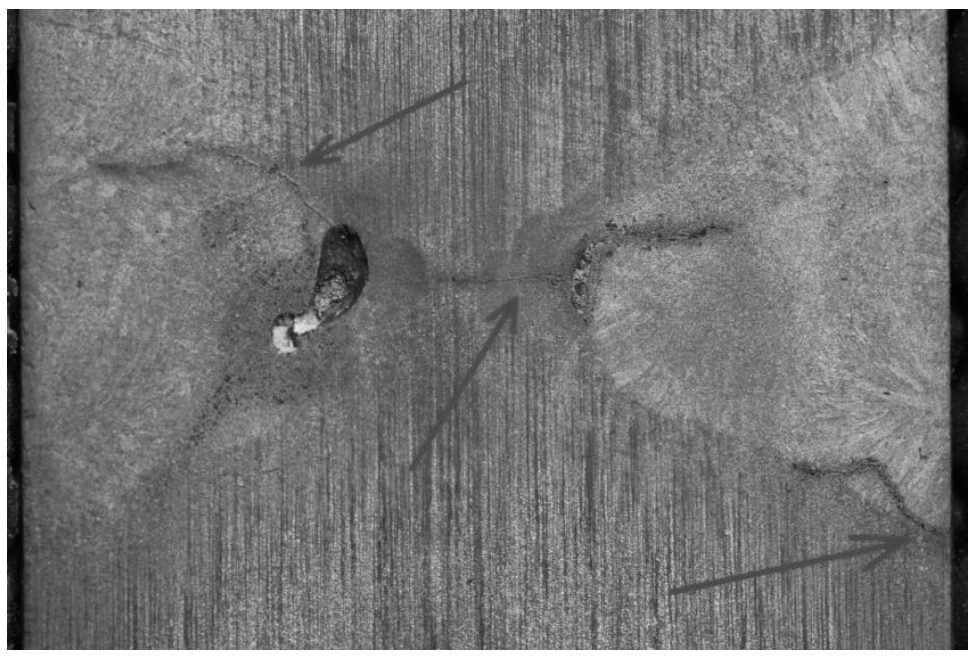

Fig. 4 Initiation a crack growth from inner defect.

- In order to make the welded joint more resistant to fatigue damage under a cyclic loading, it seems purposeful to reduce the notch effect of the weld toe. This is achievable by recasting the weld toe by TIG technology or by changing the toe's geometry by a mechanical machining. However, the fact remains that by this treatment only the fatigue resistance of the welded joint in the range of the high-cycle fatigue can be increased, since under loadings with higher amplitude the technological notch of the welded joint becomes dominant and the size of this notch can not be changed after the execution of the welded joint.

\section{REFERENCES}

[1] Eurocode 3. Design of steel structures. Part 1-9: Fatigue, UNI ENV 1993-1-9, 2005. European Committee for Standardisation.

[2] CASAVOLA, C.\& PAPPALETTERE, C. Industrial application of a new local strain method for fatigue strength evaluation of welded structures. In Advances in experimental mechanics. Bari: McGraw-Hill, 2004. pp. 234-235. ISBN/ISSN: 88386 6273-8.

[3] ŠULKO, M. Fatique damage detection by hardness tests, In Strojné Inžinierstvo 2003. Bratislava: Slovak University of Technology, 2003, pp. 5.-6.

[4] MARGETIN, M. \& ĎURKA, R. \& CHMELKO V. Influence of geometrical and technological notches of welded components on fatigue life time. In Applied Mechanics 2012: 14th Conference. Plzeň: University of West Bohemia, 2012, pp.101-104. ISBN 978-80-2610097-3

[5] GARAN, M. Monitorovanie únavového poškodenia snímaním deformačného stavu. Dizertačná práca, Bratislava, STU v Bratislave SjF, 2010. 130 pp

[6] BILÝ, M. Vrubový součinitel v únavě. Strojirenství 30, 1970, č. 8

[7] MARGETIN, M. Príspevok k hodnoteniu únavovej životnosti zvarových spojov. Dizertačná práca. Bratislava: STU v Bratislave $\mathrm{SjF}, 2013.92$ pp.

[8] HOBBACHER, A. et al. Recommendations for fatigue design of welded joints and components (update). IIW doc. XIII-1965-03/XV-1127-03; revision 2006. 